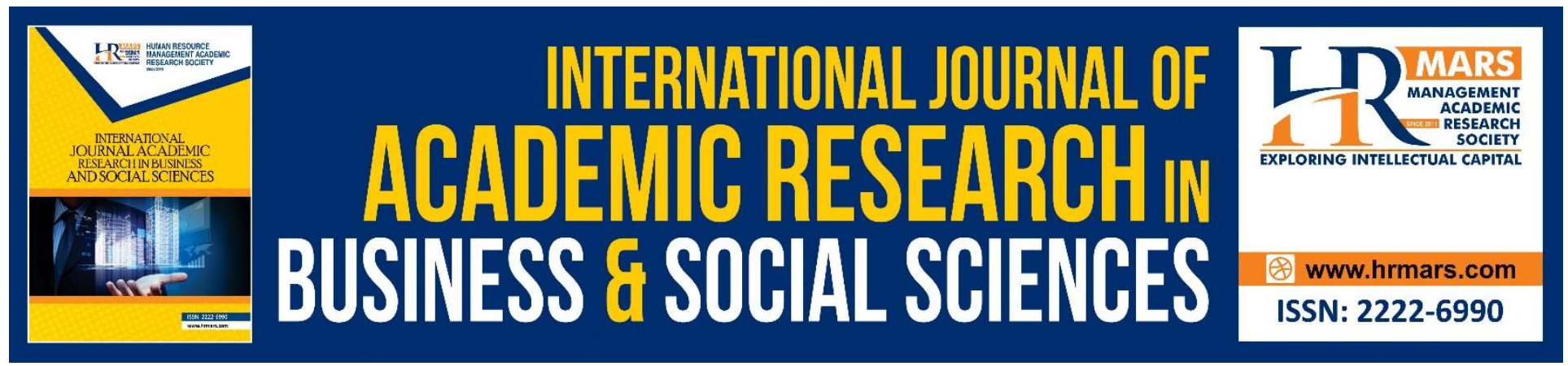

\title{
Valmiki Ramayana: A Spiritual Hermeneutic Reading
}

\author{
Puganeswari Balakrishnan \& Rahimah A. Hamid
}

To Link this Article: http://dx.doi.org/10.6007/IJARBSS/v8-i10/5294

DOI: $10.6007 /$ IJARBSS/v8-i10/5294

Received: 30 Sept 2018, Revised: 27 Oct 2018, Accepted: 02 Nov 2018

Published Online: 03 Nov 2018

In-Text Citation: (Balakrishnan \& Hamid, 2018)

To Cite this Article: Balakrishnan, P., \& Hamid, R. A. (2018). Valmiki Ramayana: A Spiritual Hermeneutic Reading. International Journal of Academic Research in Business and Social Sciences, 8(10), 1235-1244.

\section{Copyright: (c) 2018 The Author(s)}

Published by Human Resource Management Academic Research Society (www.hrmars.com)

This article is published under the Creative Commons Attribution (CC BY 4.0) license. Anyone may reproduce, distribute, translate and create derivative works of this article (for both commercial and non-commercial purposes), subject to full attribution to the original publication and authors. The full terms of this license may be seen at: http://creativecommons.org/licences/by/4.0/legalcode

Vol. 8, No. 10, 2018, Pg. 1235 - 1244

Full Terms \& Conditions of access and use can be found at http://hrmars.com/index.php/pages/detail/publication-ethics 


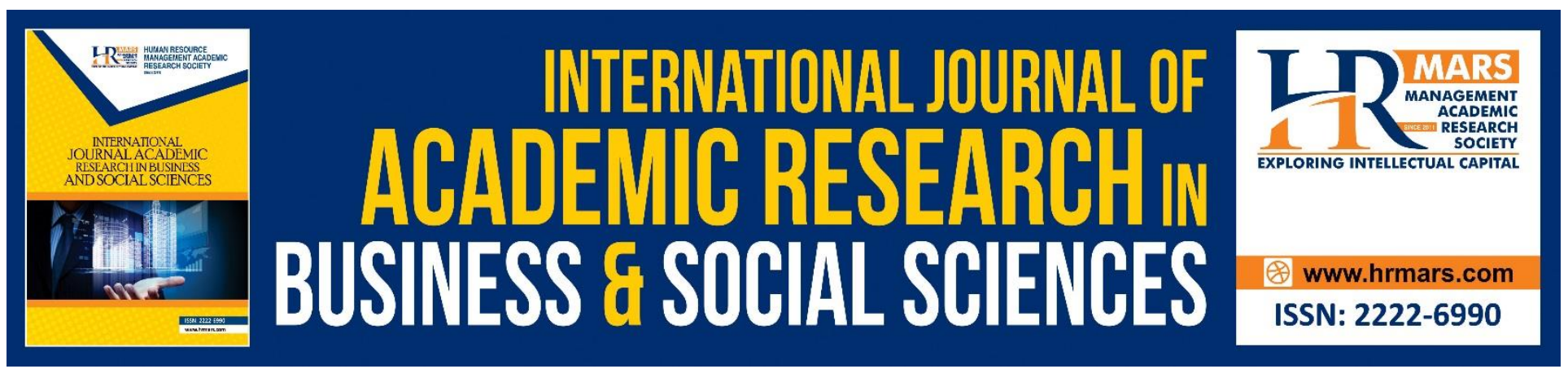

\title{
Valmiki Ramayana: A Spiritual Hermeneutic Reading
}

\author{
Puganeswari Balakrishnan and Rahimah A. Hamid \\ Pengajian Ilmu Kemanusiaan, Universiti Pusat Sains Malaysia, 11800 Pulau Pinang \\ Malaysia
}

\begin{abstract}
Ramayana is a Hindu epic literature that is popular among the traditional Indian community. The Ramayana is known as the masterpiece of the Indian traditional literature. The original text of the Ramayana was written in Sanskrit by Valmiki in the $2^{\text {nd }}$ Century. Currently, there are many versions and revisions of the Ramayana. The author of the revised version Ramayana included the cultural values and the societal norms without changing the original context of the tale as written by Valmiki. For the purpose of this study, a simplified version of Valmiki Ramayana, which was adapted by Rajendra Tandon was used. In 2013, Valmiki Ramayana was translated to English and published by Rupa Publication. The tale of Ramayana was recited by Rajenda, with the aim to ease the readers' understanding of its contents. In this study, the Valmiki Ramayana was analysed based on the hermeneutic spiritual theory introduced by Md. Salleh Yaapar. The rationale behind this is because Valmiki Ramayana contains symbolism related to the value, norm, cultural myths and customs of the traditional India community. The study revealed the factors that promote the use of the symbolism in Ramayana.
\end{abstract}

Keywords: Valmiki Ramayana, Spiritual Hermeneutic, Indian Literature, Cultural, Myth, Hinduism.

\section{INTRODUCTION}

Ramayana is one of the famous epic masterpieces of Hindu literature. The original text of Ramayana was written by Valmiki in the $2^{\text {nd }}$ century. It should be noted that the exact date when Ramayana was written is unknown, where scholars can only provide an estimated date (N.S. Jagannathan, 2002). Currently, there are many versions of the Ramayana, including Kambar Ramayana (Tamil), Sri Ramacharit Manas (Hindi) and other versions. Ramayana, which was written by Valmiki had spread over other countries with different names, such as Hikayat Seri Rama (Malaysia), Kakawin Ramayana (Indonesia), Reamker (Cambodia), Ramakien (Thailand) and others. Moreover, there are revised version of Ramayana, including Valmiki Ramayana by Rajendra Tandon and Krishna Dharma, Devdutt Pattanaik (Example authors who work on other revised versions of Ramayana) which were written to ease the readers' understanding of the original work.

Ramayana was structured into seven chapters. A chapter is referred as Kandam. Thus, Ramayana is divided into Bala Kandam, Ayodha Kandam, Aranya Kandam, Kishkindha Kandam, 
Sundara Kandam and Yuddha Kandam and Uttara Kandam. Valmiki had written Ramayana based on the story of Sita, Rama's wife who was exiled to the forest for 14 years. Ramayana briefly described how Sita was exiled to the forest after the government spies informed Rama that Sita's chastity should be questioned as she was kidnapped by Ravana and imprisoned for a year in Lanka (now is known as Sri Lanka). Despite the fact that Rama defeated Ravana and accepted Sita (after Sita proved her chastity in a fire test), Rama's subjects questioned his credibility as the king. In addition, Rama had decided to exile Sita to the forest to fulfill his responsibility as the leader of the Ayodha empire.

The objective of this study was divided into two sections. Firstly, to identify whether the interpretation found in Valmiki Ramayana is based on the culture and mythology of the Indian culture as well as Hindu teachings. Secondly, to read and analyze the Valmiki Ramayana based on the spiritual hermeneutic theory.

\section{HERMENEUTIC SPIRITUAL THEORY BY MD SALLEH YAAPAR}

Hermeneutic is defined as a method to analyses the symbolism in a literary work from the context of literature. Hermeneutic method focuses on finding and aggregating two terms of horizons, which are the literary horizon and reader horizon (Rahimah A. Hamid, 2000). Firstly, the literary horizon is a medium to transfer the writer's internal spirituality to the metaphysics world. Literary horizon uses poetic words laden with spiritual advices for the readers through the symbolism from the real world or the restricted reality. This helps to illustrate the meaning of the unrestricted reality in the world of metaphysics. Consequently, the reader would be able to understand, or close to understand the author's intended meaning while writing a literary work. Secondly, the reader horizon emphasizes hermeneutic spiritual reading of a work, which will lead to the discovery of the internal meaning of a work through the readers' reading activities. The intended meaning is embedded in the symbolism, which has to be carefully separated from its meaning. This allows the readers to understand the spiritual message that the author intends to deliver in his literary work.

The spiritual hermeneutic theory was introduced by Md. Salleh Yaapar. The theory is appropriate to study the figurative meaning through the use of various symbolism, which the meaning can be further interpreted. Moreover, spiritual hermeneutic develops the understanding of the literal meaning in a literary work. Even though the theory is from Islamic perspective, the attributes of the spiritual hermeneutic theory can be applied in other traditional literature and spiritual texts. This theory is divided into two interlinked attributes, namely exoteric exegete and esoteric exegete. According to Md. Salleh Yaapar (2002), exegete is defined as the enjoyment in the form of tangible and meaning. Hence, this method depends on the aspects of rational thinking of the human mind.

Exoteric exegete attribute is related to external interpretation of a literary text, where it is defined as the literal interpretation of the text. The second attribute is the esoteric exegete (tawil), which is related to in-depth interpretation or symbolism in the literary text. According to Md. Salleh Yaapar (2002), esoteric exegete is related to the internal comprehension of a text. In light of this, according to the Islamic literary tradition, it can only be achieved through the use of esoteric or symbolic interpretations. According to Corbin, the etymological meaning of esoteric is 'to cause a return', where something returns to the original point (Md. Salleh, 2002). In addition, esoteric is linked to the mental experiences, which is illustrated symbolically in literary works. For example, journey across 
different state of minds into a superior world or known as malakut, and the understanding of the figurative symbolic representation in a literary work (Md. Salleh, 2002). Nonetheless, spiritual hermeneutic emphasizes the esoteric, where the interpretation of (figurative meaning) provides a clear understanding of the reality of a meaning.

\section{SPIRITUAL HERMENEUTIC IN VALMIKI RAMAYANA}

The religion of Hindu, or Hinduism can be described as a religion which focuses on the ethics in life. Furthermore, Hinduism is known as a cultural circle as it is a way of life, rather than merely a religion. Hindu could be the term used by Persian invaders' lived across or along the bank of the Shindu as the Persians pronounce 's' as ' $h$ ' (Balakrishnan \& Sony, 2014).

The Ramayana is an ancient epic that summarizes the fundamental philosophy of Hinduism (Arvind \& Mark, 2014: 893) as written in the book of Veda. Veda is considered as a classic or an ancient epic in Indian literature with high-quality work. The Veda contains language of god in the form of a book. The book sparks high-level thinking and philosophical evaluation. Furthermore, it contains a range of knowledge on human life, culture, myth, and religion. There are four types of Veda or veds, namely Rig Veda, Sama Veda, Atharava Veda and Yajur Veda.

Myths have inherently become embedded into the spiritual aspects of the culture and literature of the Indian community. Mythology involves spirituality, which is presented by many ancient authors including Valmiki through his work like Valmiki Ramayana. Mythology is considered sacred and true forms in the spiritual tradition of Hinduism. Hence, P. Lal described that Indian literature without the element of mythology does not have any identity, or "When a mature literature loses myth; it loses qualities which no dynamic self-respecting culture" Rahimah A. Hamid (2000).

Valmiki Ramayana documented the birth of Rama, his marriage to Sita, Rama's quest against the evil, Sita abduction by Ravana and Sita's fire test or Agni parakshai. Rajendra Tandon analyzed the Valmiki Ramayana and revised the epic. The revised version embedded the aspects of spiritual hermenustic similar to the original author, Valmiki. In addition, the esoteric interpretation is observed through several occurrences that fit the attributes of spiritual hermeneutic's in Valmiki Ramayana in selected events.

\section{The Divinity of Rama}

The esoteric (Tawil) interpretation of spirituality illustrates that Valmiki portrayed Rama as an ideal and a religious human who fought against the evil. This was stated by Rajendra in his adaption of the Valmiki Ramayana. The initial story or Bala kandam is about the story of an emperor, Darasata, who was the ruler of Ayodha. He had three wives namely Kaushalya, Kaikeyee dan Sumitra. Nonetheless, Dasarata was not blessed with a child to continue his family lineage. Thus, Dasarata performed a religious ritual known as Putrakamesti yagam to summon the gods to grant him a child. The Yagam (Putrakamesti) was conducted by Rishyashringa, a cleric or a sage, guided by the chants written in Atharva veda. At the end of the ritual, the gods granted the offering in the form of sweets that could help the three queens to get pregnant through the fire used in the ritual. This event was documented in Valmiki Ramayana as follows; 
INTERNATIONAL JOURNAL OF ACADEMIC RESEARCH IN BUSINESS AND SOCIAL SCIENCES

Vol. 8, No. 10, Oct. 2018, E-ISSN: 222 2-6990 @ 2018 HRMARS

"Reciting mantras from the Atharva Veda, the rishi started the Putreshti yagya meant to please gods to grant the boon of a son..."

"Rajan, carrying this kheer from gods, I arrive with permission from the Prajapatis, to help you to sire several sons. This divine food gives health and prosperity. Distribute it among your capable wives and take a portion yourself. Several sons will be born to you".

(Rajendra, 2013: 12 \&13)

The esoteric interpretation of this work is evident through the depiction of Rama in the charterer's spiritual journey, which was from being a Brahman to an ordinary human due to the boon given by the God Bahraman to Ravana. The Putrakamesti yagam conducted by Dasarata had directly brought goodness to the Gods. Consequently, the Gods prayed to Vishnu and requested him to appear as a human being in the Ikshvaku lineage and as a prince to Dasarata. This event occurred as Ravana, the king of Lanka did not wish for the boon that he will be killed by a human. This event is described as below:

"Brahma thought it over. He had so blessed Ravana that the latter would not be killed by devata, gandharva, yaksha or a rakshasa. He had not included a human being in this list."

"They suggested that Vishnu be born as four sons to Dashratha so that as a human being, he could destroy Ravana without violating Brahma's commitment." (Rajendra, 2013: 12)

Therefore, the God Vishnu appeared as Rama (Swami Tapasyananda, 19762), who was the prince of Ayodha, along with Bharata, Lakshmana, and Shatrughna. This birth times of Rama and his siblings are critical in the forecast. According to Roshen Dalal (2014), who considered the perspective of Yaksa, stated that one's horoscope or Jatakam (astrology) is based on one's rasi and nachtiram (constellations). As such, a priest will forecast one's fortune based on his time of birth (Roshen Dalal, 2014). This forecast provides an overview of one's characteristics, attitude and future well-being, as described below:

"In the twelfth month on the ninth day of the waxing moon in Chaitra, Kaushalya gave birth to Rama, a child with divine attributes. The universe bowed to the child who was born under the major Gemini stars and the constellation of Cancer."

"Bharata born under Pushya [Cancri] nakshatra and Meena [Pisces] lagna was a happy-go-lucky child. Sumitra's children were born under Ashlesha [Hydrae] nakshatra and Karka [Cancer] lagna. At this time, Surya was in the ascendant. Each one of the sons of Dashratha had different qualities."

(Rajendra, 2013: 15)

\section{BIRTH OF SITA, AND WEDDING CEREMONY OF SITA AND RAMA}

The esoteric reading predominantly represented of Sita as a symbol of Goddess. The literature claims that Sita was the reincarnation of the Goddess Lakshmi, who is the wife of God Vishnu. In this revised version work, Sita appeared as an image of an ideal woman who was fostered by King Janaka. Sita 
was found by King Janaka as he was clearing a land for a ritual called Yagam. This occurrence denotes the name of Sita, which means opening of earth in Sanskrit. (Rajantheran, 1995: 33). As such, Sita was indirectly represented as the daughter of the Goddess of Earth. It should be noted that the background of Sita is unknown. Sita's attractive and flawless features denotes the perfect image of the Brahman, which is single entity of perfection for the Hindus. This is described as follows:

"One fine day, I was ploughing to level the soil for the yagya ceremonies. Miraculously, in one of the furrows ripped by the blade, a girl child appeared. I named her Sita after the sharp line drawn by the plough. With time this daughter of mine, born of the earth, grew into a charming maiden." (Rajendra, 2013: 45)

Furthermore, the esoteric interpretation is observed through the suvavaram (competition held in royal selection for princess prospective husband through variety competition) marriage of Rama and Sita. Their marriage symbolizes the internal openness and acceptance of a spouse as one's partner till death. Sita's and Rama's wedding was conducted after Rama successfully lifted the magic bow and arrow in a competition. It was held by King Janaka to choose an ideal husband candidate for his daughter, Sita. It should be noted that the magic bow and arrow symbolize internal and spiritual strength, as indicated below:

"I determined that Sita would be married to a warrior who could bend the sacred bow and shoot an arrow".

"I shall make an effort to lift this mighty, divine bow. I shall then try to put a string on it if I can".

(Rajendra, 2013: 45 \& 46)

\section{BANISHMENT OF RAMA, SITA AND LAKSHMANA FOR 14 YEARS}

Rama's banishment to the forest, along with Sita and Lakshmana depicts as a spiritual esoteric. Dasarata gave two boons to his wife Kaikeyee in return of saving his life during a battle between Dewa and Asura. Kaikeyee was instigated by Manthara to succeed the throne to Bharata. Dasarata failed to convince Kaikeyee to withdraw her decision. Hence, he agreed with Kaikayee's request. Thus, Rama was exiled to the Dandakaranya forest for 14 years. Moreover, Rama voluntarily gave up his coronation to Bharata and went to the forest with Sita and Lakshmana. This shows Rama's filial piety towards his parents, which represents the attributes of an ideal son. This is described as below:

".... I rescued him and he offered me two boons. Raghava, I have asked him to make good that promise tonight. I want Bharata to be made the Yuvaraja and you to be exiled to Dandakaranya..."

"I am prepare to lay down my life for the sake of my father..."

(Rajendra, 2013: 73\&74)

Valmiki Ramayana depicts the spiritual and mental journeys to be endured by the all Hindu worshippers who, strive to purify their souls. Rama, Sita, and Lakshmana crossed the river Ganga in 
their journey to Chitrakoot. This journey symbolises the challenges that Rama, Sita, and Lakshmana had to overcome to cleanse their soul. Ganga river is a symbolism of a sacred site, which is a shrine and the abode for the pious. Ganga river was cited as a holy site, particularly a place for the soul cleansing among the pious Hindus (Embree, 1972). This was described as below:

"With delight, Rama looked at the divine, Tripathagamini Ganga, Her cool waters flowing free of weeds. On her bewitching banks lived many a rishi".

(Rajendra, 2013: 86)

\section{BIRTH OF RAVANA, AND SITA'S ABDUCTION TO LANKA}

The hermeneutic reading of single spiritual image of Ravana symbolises adharma or evil. Ravana hailed from generation of hermits from his father Visravas's side and the generation of demons from his mother Kaisaki's side. Nevertheless, he demonstrated the ability of a demon with the high knowledge of Veda. In addition, he gained magical powers from meditation and became the ruler of Lanka. Ravana was born with 10 heads, which are the indicators of disaster faced by the humans and nature. According to Rajantheran (1995), there were loud thunders, strong wind, and roaming of wild animals everywhere when Dasagriva or Ravana was born.

Ravana's abduction of Sita is a symbolic of the fall of Ravana (Adharma) through the abduction of Sita in the forest. This directly resulted in the war between Rama (Dharma) and Ravana (Adharma). Valmiki described the story on how Sita was abducted by Ravana in the Arayan kandam. In addition, the story was simplified by Rajendra without altering the original context. Abduction is defined as the action of taking someone with force, or through deceit by locking up the person in a secret place, due to some specific reasons (Mike Webster, 2007). The event is illustrated as follows :

"The moment Lakshmana departed, the king of the rakshasas approached Videhakumari dressed as a hermit.

(Rajendra, 2013:149)

Ravana's abduction of Sita was depicted in the text as full of force and deceit. It was illustrated that Ravana had changed his appearance as a hermit and abducted Sita to Lanka. The change of Ravana's appearance as a hermit is the symbolic of the Hindu spiritual traditions, where hermit represents a holy person who is well respected among Hindu worshipers. The Hindu worshippers practice Seva or giving the good treatment to the hermits. This is believed to increase a Hindu's merit to enter heaven. Thus, Sita was not able to say no for the visit of the hermit (Ravana) when she was alone in her hut. She feared of making the hermit angry. She worried that her future generation will receive bad luck if she was cursed by the hermit. For instance, in the text of Sakuntala by Kalidasa, the curse of a hermit was illustrated through the story of a hermit named Durwadas who cursed Sakuntala. Thus, Sakuntala lost her original appearance, where she was not recognised by her own husband, King Dusyanta. This indicates that a hermit curse is very significant as they have divine power due to their piousness. 
INTERNATIONAL JOURNAL OF ACADEMIC RESEARCH IN BUSINESS AND SOCIAL SCIENCES

Vol. 8, No. 10, Oct. 2018, E-ISSN: 222 2-6990 @ 2018 HRMARS

\section{THE STRENGTH OF HANUMAN, AND THE WAR BETWEEN RAMA AND RAVANA WITH THE HELP OF THE MONEKY ARMY (VARANA)}

Hanuman is a symbol that represents the latent spiritual and self-strength, Nonetheless, one can use a facility or medium to know his/her strength and confidence in reaching Nirwana. In light of this, Jambavan accounted the strength of Hanuman, which he had forgotten as a result of a hermit curse. Nonetheless, he regained his strength and powers when someone reminded him of his powers. Thus, Hanuman was able to cross the vast ocean to reach Lanka. Finally, he met Sita, who was Ravana's prisoner in the Asoka Garden, as depicted in

"Listening to Jambavan, and inspired by his words, Hanuman realized his powers".

(Rajendra, 2013: 236)

The esoteric of this work shows the message of good versus evil, through the battle between Dharma and adharma. The story demonstrates that good will triumph over the evil. Rama was depicted as a representation of Vishnu, whom fought against the evil to bring justice to the men. Ravana, as the demon had committed evil and cruelty to human, gods, goddesses, and etc. Ravana was very proud of his hermit powers. Ravana's cruelty was depicted through his abduction of another man's wife, Sita. Moreover, he forced Sita to fulfill his desires. Nevertheless, Sita refused to adhere to Ravana's wishes. Sita's abduction is a symbolism of the fall and death of Ravana in Rama's hand. Finally, Rama defeated the so-called immortal Ravana with the help of his monkey armies, Angada, Sugriva, Jambavan, Hanuman, and others. This was due to his hermit powers. In contrast, Ravana's carelessness or ego of not asking for a boon so that he will not be killed by humans and his pride had caused his death. This is described in:

"Rama stationed his forces according to the guidelines laid down in the shastras. Angada and Neel were placed high in the centre, in the heart of the formation..."

(Rajendra, 2013: 329\&428)

\section{AGNI PARAKSHAI, OR SITA'S FIRE TEST}

The fire test endured by Sita is a symbolism of a woman's spirituality. A chaste woman will not be harmed in the fire test or by the five elements (fire, air, water, wind, and earth). These elements will adhere to her desire regardless of the circumstance. After Rama's victory over Ravana, Sita was freed from Ravana's capture. Nevertheless, Rama did not take her back despite he had defended her honour and rectified justice or Dharma. This is because Rama could not accept the fact that Sita had been captured for a year in the Asoka garden, Lanka. Thus, he questioned Sita's chastity. In reality, Sita was known as a holy woman and the symbolic sacred fire had protected her from Ravana. Therefore, Ravana was not able to touch her as she was protected by her chastity ring.

The symbolism of a woman's chaste in spirituality is linked to the god or goddess like status. For example, Draupadi Goddess in Mahabharata is deemed as a "fierce virgin goddess" in Tamil Nadu (Devdutt, 2010). In this regard, Sita is also worshipped by Hindus as the goddess of chastity. She proved her chastity by jumping into the Yagam or fire but the God of Fire did not harm her as she was 
INTERNATIONAL JOURNAL OF ACADEMIC RESEARCH IN BUSINESS AND SOCIAL SCIENCES

Vol. 8, No. 10, Oct. 2018, E-ISSN: 2222-6990 ㄷ 2018 HRMARS

a chaste woman. Furthermore, Rama conducted the fire test to prove his wife had remained chaste to the world. This is because Rama was convinced that Sita will not succumb to Ravana's desire. This is described as follows:

"If I have not, in mind, words or deeds, transgressed the omniscient Shri Rama, or violated his memory, may Agni devata protect me".

"Maithili cannot be tarnished because she is unyielsing like a flame. Her purity is such that the evil Ravana could not have harmed her even in his thoughts".

(Rajendra, 2013: 444\& 450)

\section{FINDINGS AND CONCLUSION}

The findings of this study revealed that the spiritual hermeneutic theory is suitable to analyze the revised version of Valmiki Ramayana written by Rajendra. A realistic writing technique was presented in this study with an element of supernatural. The exoteric or spiritual interpretations found in the form of stories symbolise things like a good and justice government as shown in Rama's rule of Ayodha. Here, Rama's character is depicted as a role model and an ideal human as a guide to achieve path of Nirwana.

\section{Corresponding Author}

Puganeswari Balakrishan

Pengajian Ilmu Kemanusiaan, Universiti Pusat Sains Malaysia, 11800 Pulau Pinang

Malaysia.

Email:puga_810@yahoo.com

\section{REFERENCES}

Ashta, A., \& Mark, H. (2014). Hinduism And Microcredit. In Journal Of Management Development, Vol 33 (8/9), 891-904. Bingley: Emerald Group Publishing Limited.

Muniapan, B., \& Jalarajan, R.Y. (2014). Corporate Social Responsibility Communication From The Vedantic, Dharmic and Karmic Perspectives. In Journal Communicating Corporate Social Responsibility: Perspectives and Practice, Vol 6, 337-354. Bingley: Emerald Group Publishing Limited.

Pattanaik, D. (2010). Jaya Mahabharata. New Delhi: Penguin Books India.

Yaapar, M.S. (2002). Ziarah ke Timur. Kuala Lumpur: Dewan Bahasa dan Pustaka.

Jagannathan, N. S. (2002). The Kamba Ramayana. New Delhi, India: Penguin Books Pvt. Ltd.

Hamid, R.H. (2000). Bacaan Secara Hermeneutik. Dalam Dewan Sastera. Kuala Lumpur: Dewan Bahasa dan Pustaka.

Muniandy, R. (1995). Hikayat Seri Rama: Perbandingan Versi Melayu, Sanskrit dan Tamil. Kuala Lumpur: Dewan Bahasa dan Pustaka.

Tandon, R. (2013). Valmiki Ramayana. New Delhi: Rupa Publications India Pvt. Ltd.

Dalal, R. (2014). The Vedas. New Delhi: Penguin Books India.

Tapasyananda, S. (1976). Narayaneeyam: Bhagavata Condensed. Mylapore: Sri Ramakrishnan Math Printing Press. 
INTERNATIONAL JOURNAL OF ACADEMIC RESEARCH IN BUSINESS AND SOCIAL SCIENCES

Vol. 8, No. 10, Oct. 2018, E-ISSN: 2222-6990 @ 2018 HRMARS

Mike, W. (2007). Kidnapping: A Brief Psychological Overview. Dalam NATO Science for Peace and Security Series, 21, 231-242. Netherlands: IOS Press. 